\title{
Escaping social-ecological traps through tribal stewardship on national forest lands in the Pacific Northwest, United States of America
}

\author{
Jonathan W. Long ${ }^{1}$ and Frank K. Lake ${ }^{2}$
}

\begin{abstract}
Tribal communities in the Pacific Northwest of the United States of America (USA) have long-standing relationships to ancestral lands now managed by federal land management agencies. In recent decades, federal and state governments have increasingly recognized tribal rights to resources on public lands and to participate in their management. In support of a new planning initiative to promote sustainable land management, we reviewed scientific publications to examine relationships between tribal social-ecological systems and public lands in the region. We identified key ecocultural resources, impacts to those resources, and associated forest ecosystems, and strategies that have been piloted to redress those impacts. We found that many factors stemming from colonization by Euro-Americans have engendered social-ecological traps that have inhibited tribes from continuing traditional land stewardship activities that supported their well-being and maintained ecological integrity. These long-standing factors include legal and political constraints on tribal access and management; declining quality and abundance of forest resources due to inhibition of both natural disturbance and indigenous tending regimes; competition with nontribal users; species extirpations and introductions of invasive species; and erosion of tribal traditional ecological knowledge and relationships that are important for revitalizing resource use. As a consequence, both supply and demand for these forest resources have been reduced, as have the resilience and diversity of these ecosystems. Simply permitting resource harvest by tribal members does not sufficiently address the underlying constraints in ways that will promote tribal well-being. Escaping these traps will require addressing a gamut of ecological and social constraints through cooperative restoration efforts between land management agencies and tribes, several of which we highlight as examples. Because tribally focused restoration strategies generally align with broader strategies suggested to restore national forests in the region, they can foster both tribal well-being and ecological sustainability.
\end{abstract}

Key Words: American Indians; ecocultural resources; indigenous peoples; public lands; social-ecological restoration; social-ecological traps; stewardship; tribal rights; well-being

\section{INTRODUCTION}

Native American tribes have a long-standing and vital interest in restoring and conserving social and ecological values of public lands in the Pacific Northwest of the USA, which encompass large portions of their ancestral homelands. Trosper (2002) and Campbell and Butler (2010) found that aboriginal socialecological systems were resilient and sustained critical food resources such as salmon prior to European colonization. More recent research has detailed how the loss of influence over aboriginal lands and associated opportunities to sustain traditional lifeways has contributed to economic, diet, and health problems and has disrupted family and societal relationships among tribes in the region (Norgaard 2014a, Dobkins et al. 2016, LeCompte-Mastenbrook 2016, Norton-Smith et al. 2016, Mucioki et al. 2018). Building upon that previous research, our paper asks: "What strategies for managing national forest lands can promote ecological resources and stewardship opportunities that are important for tribes in the Pacific Northwest region?" This question calls for understanding how community well-being and ecological conditions have changed and may respond to future land management. In addition, we wanted to understand how engagement with tribes in designing and implementing management strategies would address both ecological restoration and tribal well-being. Such an integrative approach is important to fill the many gaps between narrow ecological studies of particular species and social studies of tribal communities. We narrowed our focus to ecosystems and institutional decisions for which public land agencies such as the U.S. Forest Service have primary responsibility, while recognizing broader societal factors that have contributed to social-ecological traps. In this article, we review the history that has shaped relationships between tribes and public land management in the USA, explain how we synthesized published literature to address our question, consider factors that have contributed to a social-ecological trap for tribal communities and ecosystems in the region, and finally examine strategies that have been piloted to redress those impacts.

\section{Historical context of tribal interests in public lands}

Native American populations throughout much of the Pacific Northwest of North America declined precipitously with EuroAmerican colonization that precipitated warfare, murder, and introduced diseases such as smallpox, measles, and malaria (Boyd 1999). In the wake of this decimation, the federal government asserted control over tribal lands and confined native people onto relatively small reservations or even smaller "rancherias." Many of these reservations were subsequently allotted, with parcels sold to non-Indians. Officials such as the Secretary of the Interior explained the beliefs that drove the Government's efforts to radically disrupt tribal lifeways, "In our intercourse with the Indians it must always be borne in mind that we are the more powerful party, and have uniformly regarded the Indians as the wards of the nation. We are assuming, and I think with propriety, that our civilization ought to take the place of their barbarous habits. We therefore claim the right to control the soil which they occupy, and we assume that it is our duty to coerce them, if necessary, into the adoption and practice of our habits and customs" (Delano 1872:4).

By the early 20th century, the U.S. government had assigned control over much of tribal ancestral lands to the U.S. Forest Service, Bureau of Land Management, and National Park Service 
(Keller and Turek 1999, Catton 2016). As a result of such actions, dozens of tribes have long-standing relationships to ancestral lands that are presently managed by federal public land agencies. The federal agencies all have a trust responsibility to protect tribal treaty rights, lands, assets, and resources (Wood 1995). When the U.S. government entered into treaties with many of the tribes in Washington and Oregon between 1853 and 1856, it committed to protect resource utilization activities, including fishing, hunting, and gathering, on lands outside the reservations (Woods 2005). In California, the U.S. government similarly negotiated 18 treaties with many tribes from 1851-1852, but the Senate refused to ratify them (Wood 2008). The U.S. government has recognized tribes as political sovereigns since its founding, but in the mid-20th century, the U.S. government terminated its recognition of many tribes, particularly in California and Oregon while continuing to transfer lands out of tribal control. For example, the U.S. government terminated its relationship with the Klamath Tribes in southern Oregon and transferred their reservation to form much of the Winema National Forest (Catton 2016). The massive shift in land tenure and lifeways resulting from Euro-American colonization engendered enduring poverty in many tribal communities. A striking example is the Karuk Tribe, $90 \%$ of whose members live below the poverty line (Norgaard et al. 2011). The Tribe retains only 321 ha in small, fragmented parcels that represent a miniscule fraction of their ancestral territory; by contrast, $98 \%$ of that territory is now managed by three national forests (Norgaard et al. 2011).

\section{Social-ecological traps}

Recent literature has described social-ecological traps as persistent, undesirable states that result from interactions among actors, institutions, and ecological dynamics (Cinner 2011, Tidball et al. 2016). Such interactions include governance changes in which local customary managed systems are eroded and supplanted by state control over common property resources and nationally appointed professionals, and pressures to unsustainably exploit resources due to poverty and population growth (Cinner 2011, Enfors 2013). Social traps may be exacerbated by environmental problems such as droughts. However, analyses of social-ecological traps focus on two-way interactions between societies and the environment that become maladaptive particularly because of short-sighted or misguided human thinking and actions (Tidball 2016). Previous work on socialecological traps has highlighted management of U.S. forests. For example, Carpenter and Brock (2008) summarized how communities and forests were more vulnerable to damaging wildfires as a product of historical timber harvest, fire suppression, settlement, and climate change that created dense forests interspersed with vulnerable human dwellings. Such research has suggested that traps often represent a slow social response to environmental problems or a myopic focus on maximizing desirable products such as timber (Holling and Meffe 1996, Carpenter and Brock 2008), and they have not emphasized the extent to which traps resulted from the U.S. government establishing hegemony over tribal nations. The imposition of $U$. S. governance separated tribes, in both physical and nonphysical ways, from their aboriginal lands and resources, and subsequent urban and agricultural development, including dam construction, greatly impacted fish and wildlife populations that were important to tribal people. Over a century ago, forest managers rejected Native American land-tending practices such as intentional burning because they regarded them as misinformed, grounded in superstition, and inconsistent with producing the services that they believed the general public expected from those forests, in particular, timber (Jack 1916, Leopold 1920, Greeley 2000). Although those decisions may be attributed to insufficient foresight, it is important to recognize that they were deliberate rejections of tribal interests and understandings, as well as the recommendations of some non-Native foresters who urged further consideration and research on the likely benefits of socalled "light burning" (White 1920).

\section{Growing tribal influence in public lands management}

In recent decades, many tribes have experienced economic prosperity resulting from utilization of natural resources on their remaining lands, as well as from tribal gaming and other enterprises (Cornell and Kalt 1998). Such examples particularly include tribes in Oregon and Washington with ratified treaties and fairly extensive, forested reservations within their original ancestral territories. This economic development has aided and coincided with increases in political power, successful lawsuits, and scientific expertise (Breslow 2014, Catton 2016). Tribes have successfully pursued various legal remedies to improve conditions of water, fish, and other natural resources and have more influence over management of public lands and waters (Nie 2008, Gosnell and Kelly 2010, Breslow 2014). Court rulings have supported tribal efforts to restore the productivity of social-ecological systems by requiring state governments to comanage salmon populations with tribes and to take more actions to restore those populations by reducing barriers to fish passage (Breslow 2014). Removal of several large dams in the region has represented watershed events for these restoration efforts, both symbolically and literally (Pess et al. 2008).

The U.S. government instituted the Northwest Forest Plan (NWFP) in 1994 to conserve old-growth forest ecosystems within the range of the northern spotted owl (Strix occidentalis caurina) (Espy and Babbitt 1994). Over 70 federally recognized tribes, and many more tribes that are not currently recognized, have tribal lands and/or ancestral territory within the NWFP boundary (Fig. 1) (Stuart and Martine 2005). The NWFP stressed the importance of consultation and cooperation with those tribes (Espy and Babbitt 1994). However, beyond its focus on conserving old forests and salmonids, it did not consider more proactive efforts to foster resources of value to tribes or tribal management practices. The NWFP also did not emphasize the ecological importance of fire and the influence of Native Americans. However, the 10-, 15-, and 20-year NWFP monitoring reports (Stuart and Martine 2005, Harris 2011, Vinyeta and Lynn 2015) specifically considered the effectiveness of consultation with tribes, and they also devoted increasing attention to whether tribes had access to forest resources and places that were important for cultural, subsistence, or economic reasons, particularly those protected by tribal treaty rights.

Since the NWFP was adopted, federal policies have further recognized the significance of tribal rights to resources from public lands and tribal participation in their management. That broad evolution in federal policy has supported cooperative agreements with tribes, and rights to treaty resources have served as an impetus for formal comanagement arrangements. Despite such examples, many tribes have contended that national forests have not sufficiently fulfilled their potential to better support the 
Fig. 1. Present-day tribal reservations, and ancestral lands mapped as cessions to the U.S. Government in Library of Congress records (https://memory.loc.gov/ammem/amlaw/lwss-ilc.html) within the Northwest Forest Plan area in Washington and Oregon (left), and northern California (right), USA. Asterisks denote tribal lands outside the boundary belonging to tribes that have ancestral lands within the boundary.

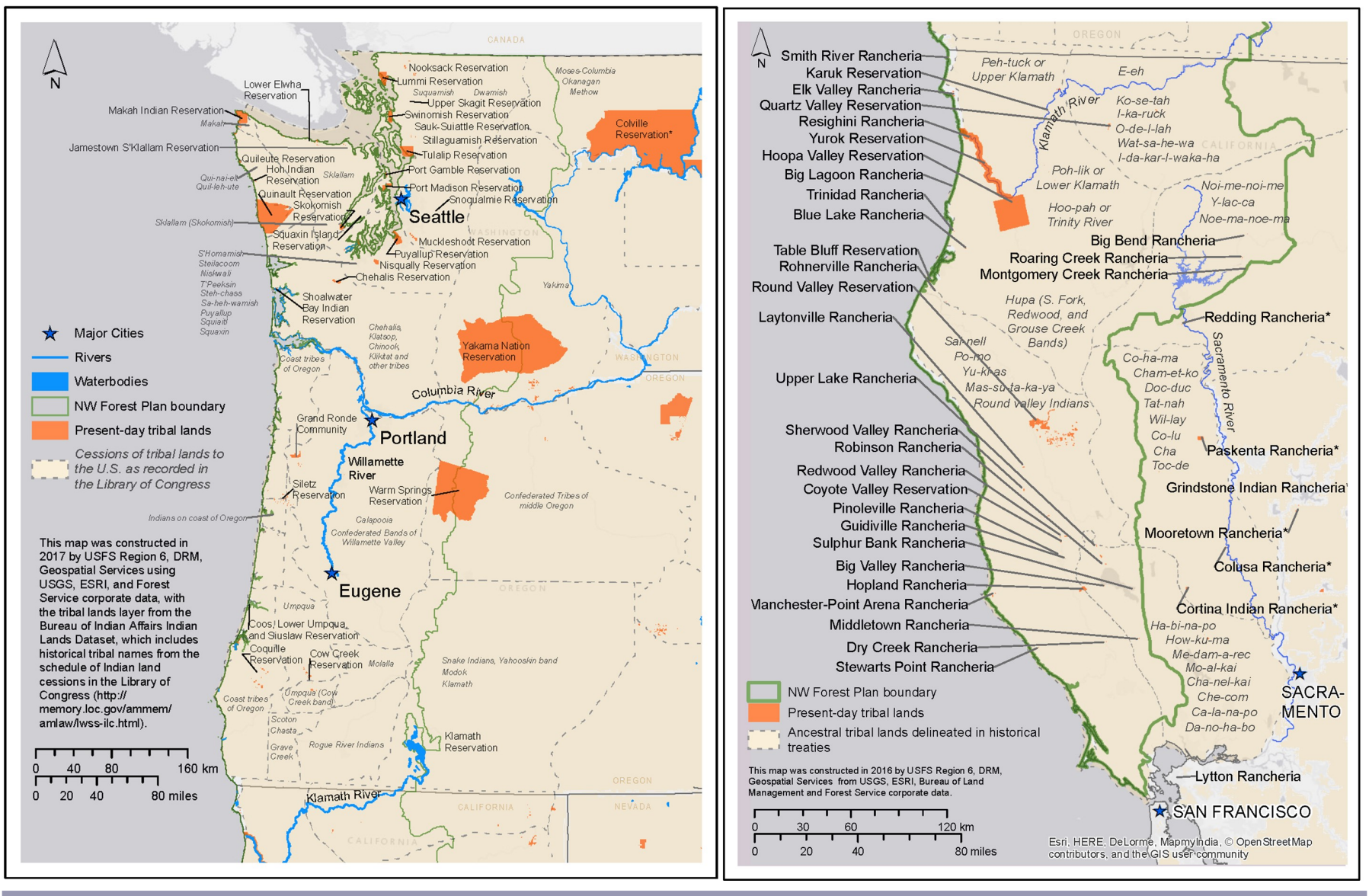

cultural, economic, and ecological sustainability of tribal communities and sustain ecosystems that evolved with indigenous caretakers. However, the latest land management planning rule for national forests in the USA includes objectives not only of contributing to "economic and social sustainability" (Section 219.8 (b)), but also providing for "protection of cultural and historic resources," and "management of areas of tribal importance" (Section 219.10(b)(1)(ii) (Office of the Federal Register 2012). Because national forests in the Pacific Northwest are embarking upon major updates to their land management plans under this new directive, examining how the interests of tribal communities can be considered in public lands management is a timely endeavor.

\section{METHODS}

In 2015, Forest Service land management officials commissioned a science synthesis to help inform the new land management plans. One of the key questions posed by managers was, "What is the capacity of the Northwest Plan area to provide for Native American first foods (e.g., salmon (Oncorhynchus spp.), elk (Cervus elaphus), huckleberry (Vaccinium spp.), camas (Camassia spp.), etc.), and is active management called for?" "First foods" is a term that some tribes have applied to traditional foods that have been and remain very significant in their diet and culture (Lynn et al. 2013). As part of our role in compiling that synthesis, we considered that question alongside opportunities to promote tribal community well-being and sustainability of federal forest lands more broadly. In particular, we considered how historical changes in the relationships between tribes and forests in the Northwest Forest Plan area had impacted social and ecological systems, and how restoring tribal stewardship practices could foster greater sustainability.

To prepare the science synthesis requested by managers, we and two other colleagues (see Acknowledgments) reviewed scientific publications that examined relationships of tribal social-ecological systems to public lands in the region. Through our review, we identified key ecocultural resources, impacts to the sustainability of those resources and associated forest ecosystems, and strategies that have been piloted to redress those impacts. Because our research question encompasses many social and ecological topics, neither a comprehensive search for all relevant literature nor a quantitative analysis was feasible. Therefore, we conducted a narrative review, which is particularly useful for presenting alternative perspectives, historical development of ideas, and other conceptual frameworks, rather than evaluating the efficacy of particular interventions (Koricheva and Gurevitch 2013). We took 
several steps to promote the reliability of our findings by listing our sources with the public and expanding that list based upon external feedback. We began with lists of references used in previous science synthesis and monitoring reports that had been published since the NWFP was adopted in 1994 (Lynn et al. 2011, 2013, Voggesser et al. 2013, Long et al. 2014, Vinyeta and Lynn 2015). We expanded our search by reviewing references submitted by members of the public through a portal that was open in the winter of 2015-2016: http://www.fs.fed.us/pnw/research/sciencesynthesis/literature-database.shtml. The initial draft of the full science synthesis, including the section on tribal ecocultural resources, underwent a formal peer review coordinated by the Ecological Society of America, and was also presented for the public so they could provide feedback to the peer reviewers. We revised the draft chapter in response to five peer reviews, which incorporated many detailed responses to the draft findings from several tribal representatives in the Pacific Northwest. The reviews suggested additional references as well as specific topics regarding ecocultural resources or dynamics; in response, we conducted additional targeted searches using Google Scholar (https:// scholar.google.com) and the U.S. Forest Service's Treesearch database (http://treesearch.fs.fed.us/).

We ended up including over 300 sources, which are listed in the public database cited above, so that others can review the same sources and identify gaps. We sought to limit the review to sources that were peer reviewed and were publicly available, so that both managers and members of the general public could also examine their findings. Therefore, we drew most heavily from articles published in scientific journals. However, we also included agency reports, academic books, theses, and dissertations to consider issues that emerged as significant yet were insufficiently addressed in journal articles. Consequently, we reviewed a dozen theses and dissertations as well as many reports that were conducted with support and participation from tribal communities. For this article, we winnowed out key findings from the larger synthesis that related to the concept of social-ecological traps and strategies for promoting sustainability.

We did not conduct primary research with tribal communities for the synthesis. Because there are dozens of federally recognized tribes in the region (along with many more that are not currently recognized formally by the U.S. government), undertaking primary research poses many challenges. In particular, relationships between tribes and agency scientists concerning ecological practices and knowledge take considerable time to build, and even then, tribes often choose to keep traditional knowledge confidential to safeguard it (Bussey et al. 2016). Much traditional knowledge is closely tied to spiritual beliefs, and knowledge holders typically adhere to particular protocols to ensure propriety. However, the reports by Dobkins et al. (2016) and Karuk Tribe and Cultural Solutions (1999) demonstrate how some agency efforts have gathered primary information on natural resource issues through partnerships with universities, tribes, and/or tribal organizations. Indeed, the current Land Management Planning Rule requires National Forest System decision makers not only to use "best available science," but also to request information about native knowledge, land ethics, cultural issues, and sacred and culturally significant sites (Office of the Federal Register 2012).
Considering only published scientific information may exclude traditional tribal knowledge that has not been referenced in scientific publications and it also risks perpetuating long-standing power imbalances (for example, by giving more recognition to researchers than individuals who share knowledge with them) and reinforcing barriers to integrating traditional knowledge into land management (Gavin et al. 2015). Tribal knowledge is often passed down orally in native languages rather than specialized, technical terminology often used in land management (Ellis 2005). Land managers may discount traditional knowledge that does not seem to fit with their understandings of particular issues (Bussey et al. 2016). Furthermore, tribal knowledge may be distorted or diminished as it is "scientized," or translated into Western scientific syntheses written in English (Agrawal 2002). Consequently, even the conventional practice of scientific review and decision making may reinforce a trap that tribal practitioners experience when attempting to reinstitute traditional practices (LeCompte-Mastenbrook 2016); specifically, they may feel their knowledge is only accepted as reliable once professional scientists have transformed it through experiments directed by nontribal land managers.

\section{RESULTS AND DISCUSSION}

\section{Development of traps that constrain tribal stewardship}

Many social and ecological factors have contributed to longstanding traps that have inhibited tribes and their individual members from maintaining traditional practices that are important for sustaining community well-being. These factors include legal and political constraints on tribal land tenure, access, and stewardship; decline in the quality and abundance of forest products due to inhibition of both natural disturbance and indigenous tending regimes; competition with nontribal users; species extirpations and introductions of invasive species; and erosion of tribal traditional ecological knowledge and relationships that are important for revitalizing resource use (Fig. 2; Table 1). Specific factors that have reinforced this trap are described below with reference to several published studies that focus on national forests within various parts of the NWFP area.

Fig. 2. Factors contributing to a social-ecological trap by disrupting tribal relationships with ancestral ecosystems. We present the factors in a counter-clockwise direction to suggest that these processes are running counter to an expected or desirable order.

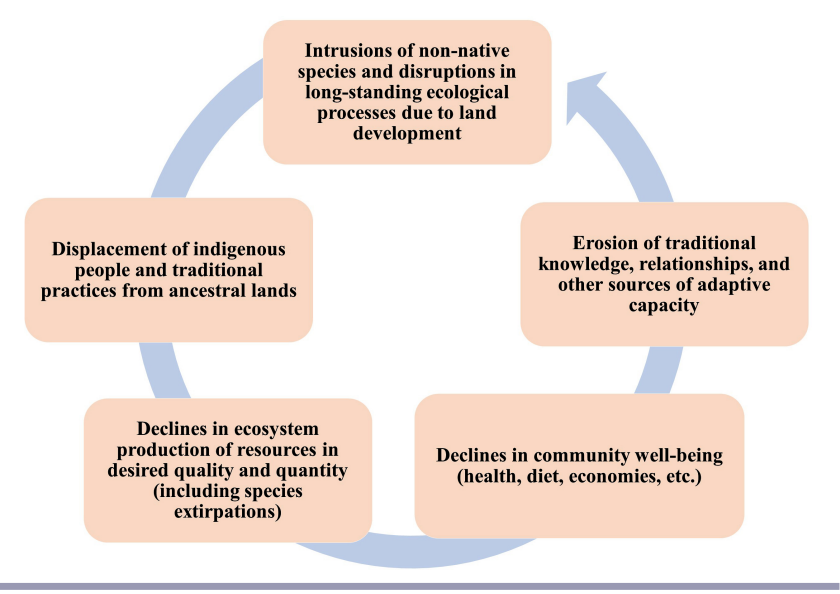


Table 1. Factors that have contributed toward a social-ecological trap paired with strategies to promote tribal well-being and sustainability, and recent examples from the Northwest Forest Plan area.

\begin{tabular}{|c|c|}
\hline Degradative Factors & Parallel Restorative Factors Related to Public Lands Management \\
\hline Removal to reservations anc & Return of public lands to tribal control \\
\hline lands and prohibitions on tribal management & operative or comanagement, particularly within designated tribal stewardship areas \\
\hline Termination of tribes in mid-20th century by Congress & $\begin{array}{l}\text { Re-recognition of tribes by USA beginning in late 20th century (along with recognition of } \\
\text { previously unrecognized tribes) }\end{array}$ \\
\hline $\begin{array}{l}\text { Fire exclusion and suppression beginning in early } 20 \text { th } \\
\text { century }\end{array}$ & Restoration of fire regimes, including cultural burning, using adaptive managements \\
\hline Restricting active management, including thinning & Supporting active management, including thinning treatments \\
\hline Wildlife extirpations, such as California condor, grizzly & Facilitation of wildlife reintroductions (typically led by state agencies and the U.S. Fish and \\
\hline bear, beaver, and wolf, among others & Wildlife Service, but sometimes with involvement of tribes and the U.S. Forest Service) \\
\hline Damming of rivers & Facilitation of dam removal and restoration of associated aquatic ecosystems \\
\hline Contamination of streams and forests & $\begin{array}{l}\text { Restrictions on use of chemicals such as pesticides, herbicides, and fire retardants; } \\
\text { notification and tracking systems; and enforcement and cleanup }\end{array}$ \\
\hline & Designation of exclusive gathering areas and seasonal access closures \\
\hline s by tribal members & Maintaining roads to provide access, especially by tribal elders \\
\hline Erosion of traditional knowledge & $\begin{array}{l}\text { Support for monitoring and research regarding ecocultural resources, and consideration of } \\
\text { traditional knowledge in planning and implementation }\end{array}$ \\
\hline $\begin{array}{l}\text { Degradation of intertribal networks, including trade } \\
\text { and sharing }\end{array}$ & Cooperative agreements with multiple tribes and intertribal organizations \\
\hline
\end{tabular}

\section{Displacement of Native Americans and their traditional land- tending practices}

As described in the introduction, the deaths and displacement of Native Americans were followed by government policies that prohibited traditions of land tending and harvest. For example, in 1912, the federal government authorized rewards for stopping supposed "incendiarists" - tribal members who were setting fires on the Hoopa Valley reservation (Huntsinger and McCaffrey 1995). Similarly, many tribal members were arrested as they attempted to assert their treaty rights to harvest fish (Breslow 2014). During much of the 20th century, local tribes had little influence over resource management on federally managed lands for a variety of reasons, including limited tribal institutional capacity, dismissal of tribal traditional knowledge and concerns, and inconsistent federal recognition and policies (Record 2008, Catton 2016). Public land management during that era, including fire suppression and punishing Native Americans for burning and harvesting in accordance with traditional practices, evoked considerable distrust of land management agencies (Norgaard 2014b, Dobkins et al. 2016). Ingrained fear of persecution, fines, arrests, and disputes over acceptable conservation practices have reinforced the historical constraints on tribal stewardship (Coder et al. 2005).

\section{Decline in resource quality and quantity, leaving areas no longer suitable for harvest}

Tribes and researchers have reported on declining productivity of ecosystems that long provided key ecocultural resources (Voggesser et al. 2013, Vinyeta and Lynn 2015). Land development and alteration of hydrological systems (including damming of rivers) for Euro-American settlement and agriculture degraded the abundance, accessibility, and quality of freshwater mussels (Unionidae sp.), salmonids, candlefish (Thaleichthys pacificus), lamprey (Lampetra tridentata) (Fig. 3), and sturgeon (Acipenser spp.) (Breslow 2014, Norgaard et al. 2017). Most anadromous fish species, which are a staple of traditional tribal diets, have declined to levels that have caused them to be protected under the federal Endangered Species Act.
Fig. 3. A traditional tribal meal demonstrates an array of ecocultural resources, including lamprey and salmon prepared on coast redwood and western redcedar sticks over a madrone wood fire along the Salmon River, California, USA. April 2016.

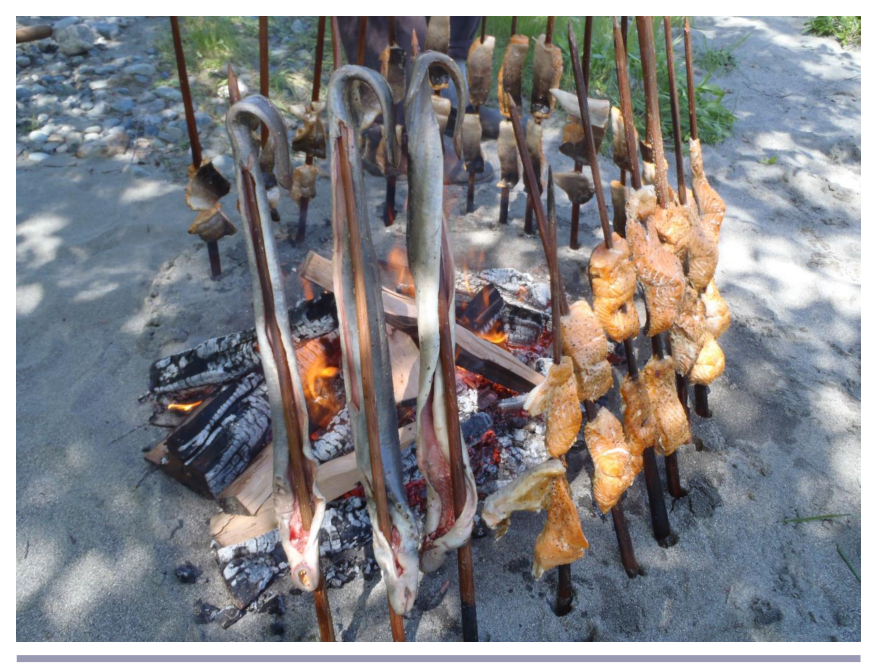

The NWFP monitoring reports note that some tribal respondents regard the NWFP as having improved the condition of terrestrial and aquatic ecosystems by providing protection for old-growth forest and aquatic habitats (Vinyeta and Lynn 2015). However, these reports and research conducted with tribes (LeCompteMastenbrook 2016) also describe how fire suppression and minimal disturbance approaches, especially within designated wilderness areas and late-successional reserves created by the NWFP, have inhibited availability of important resources such as huckleberries and elk. Fire suppression has reduced the occurrence of both high-severity, stand-replacing fire, especially in moist forests, as well as low-severity fires, especially in dry forests (Miller et al. 2012, Reilly et al. 2017). These changes in fire 
regime have facilitated widespread encroachment and densification by shade-tolerant conifers and degraded the quality of hardwood stands in forests and woodlands, grasslands and wetlands, and coast redwood (Sequoia sempervirens) forests (Zald 2009, Engber et al. 2011, Hamman et al. 2011). For tribes, an important consequence has been declines in shade-intolerant, or disturbance-dependent understory plants and fungi used for food, fiber, and medicine, including various berries, camas, morels (Morchella spp.), and beargrass (Xerophyllum tenax), among many others (Charnley et al. 2008, Dobkins et al. 2016). Furthermore, populations of game animals have declined in many areas due to lack of fire, forest canopy closure, and reductions in forage (Peek et al. 2002). Some tree species of special importance, such as Alaska yellow-cedar (Callitropsis nootkatensis), which is an important source of tribal weaving materials, appears highly vulnerable to climate change within its range (Coops and Waring 2011). However, other species highly valued by tribes, including California black oak (Quercus kelloggii), Oregon white oak (Quercus garryana), and tanoak (Notholithocarpus densiflorus) may even increase with warming climate despite the threat of increased wildfires (Halofsky et al. 2016). Severe burns may help valued hardwoods, which can resprout, over their conifer competitors (Cocking et al. 2014). However, tribal members have reported that the services that many of these hardwoods provide, such as high quality and abundant nut production, have declined due to the lack of tending practices that have long been used to maintain large, productive mature trees and control populations of native insect pests (Anderson 2005, Bowcutt 2013, Halpern 2016). Researchers have contended that reduction in Native American harvest of geophytes, basketry shrubs, seed-bearing graminoids, nut-bearing trees, and other plants has contributed to declines in the diversity and productivity of woodlands, wetlands, and prairies by decreasing the amount of clearing, burning, and other ground disturbances (Turner et al. 2003, Anderson 2005, Schultz et al. 2011).

\section{Community members suffering poorer health and food and economic insecurities}

Ceremonies held by many tribes in the Pacific Northwest celebrate the annual arrival of salmon, venison, berries, and edible roots as foods that have supported tribal communities for generations (Mack and McClure 2002). Salmon and tanoak may have provided half of the traditional diet among members of the Karuk Tribe in California; however, consumption of salmon among tribal members has dropped to an average of $2.25 \mathrm{~kg}$ per person per year, down from an estimated $200 \mathrm{~kg}$ per person per year (Norgaard et al. 2011). The inability of many tribal members to harvest such foods and other products has been linked to a host of social ills, including diminished tribal food security and health (MacDougall 2008, MacKendrick 2009, LeCompte-Mastenbrook 2016, Mucioki et al. 2018), disrupted family and social relationships (Willette et al. 2016, Norgaard et al. 2017), and reduced quality of life (Norgaard 2014b). These environmental effects coalesce with broad impacts of colonization on cultural identity and economic opportunities, which have led to elevated rates of suicide and other harmful behaviors within tribal communities of the region, particularly among youth (Strickland et al. 2006).
Erosion of traditional ecological knowledge, intertribal networks, and other sources of adaptive capacity

As resource availability and access have declined, elders have had fewer opportunities to practice stewardship traditions and teach them to youth, as well as reduced incentives to do so (Whyte 2013, LeCompte-Mastenbrook 2016). Fear of persecution contributed to the loss of knowledge and intergenerational transfer, as poignantly described by tribal members from a different part of the USA, who nevertheless confronted similar pressures: "Commonly enough, after [confinement to the] San Carlos [Reservation], many older Dilzhe'e who witnessed what had happened to those who resisted simply clammed up. Talking about the old ways was at best melancholy and often counter-productive. Cultural information - which had been the domain of all Apaches -was now relegated to the internal archive of individuals and certain families who passed it on in degrees with variable success. Elders often advised children and grandchildren to 'keep it in their hearts.' Others were told simply to 'forget all about those days,' or words to that effect”' (Coder et al. 2005: 279).

Once productive and familiar homelands became feral and inhospitable "wilderness" in the view of many tribal members (Anderson 2005). Many decades of displacement and land use by Euro-Americans have obscured much of the evidence of historical activities by Native Americans, including archaeological sites and trees bearing fire scars and other evidence of tribal use and stewardship (Turner et al. 2013). Furthermore, collective understanding of reference conditions is likely to have become distorted as memories of past conditions are lost and people become habituated to more recent degraded conditions. This dynamic that has been dubbed "shifting baseline syndrome" (Papworth et al. 2009), and is another factor that self-reinforces the trap. When cultural keystone species are reduced or eliminated from a tribe's ancestral territory, then the associated cultural traditions and knowledge decline along with the material wellbeing of tribal communities (Colombi 2012, Cuerrier et al. 2015). Historical intertribal networks have long been an important source of adaptive capacity by facilitating exchange of resources, cultural practices, and knowledge systems (Turner and Cocksedge 2001, Trosper 2003, Papiez 2009). As people had fewer resources necessary for trade or constructing regalia, canoes, and other traditionally important items, their capacity to sustain traditional relationships and cultural systems, such as potlatch and first foods or world renewal ceremonies, has deteriorated. These cultural systems historically played important roles in maintaining resilience of social-ecological systems in the region (Trosper 2003).

\section{Exacerbating factors}

A range of other stressors, including climate change, invasive species (including sudden oak death (Phytophthora ramorum), Port Orford cedar disease (Phytophthora lateralis), Himalayan blackberry (Rubus armeniacus), knotweeds (Polygonum spp.), and many others described by Pfeiffer and Ortiz (2007)), extirpations of culturally important animals, contamination of streams by toxins and use of herbicides in forests, and changes in land use have reduced the availability of ecocultural resources and constrained their use by tribal members. An important example is illegal marijuana cultivation that has polluted ecosystems with toxic rodenticides, threatening both wildlife and fish important to tribes, and has created hazardous conditions for forest users (Gabriel et al. 2013). 


\section{Fees and access restrictions}

Attention to effects of federal policies has often focused on legal or bureaucratic barriers to obtaining resources on public lands. For example, tribes have sought to obtain large redcedar (Thuja plicata) logs, which are used to make canoes, totem poles, and other traditional craft items (Garibaldi and Turner 2004). NWFP monitoring reports (Vinyeta and Lynn 2015) have highlighted agency fees and other obstacles when attempting to obtain such logs from public lands. Recent revisions to policies that recognize tribal rights to gather forest products for traditional and cultural purposes without fees may have ameliorated some of these conflicts; however, even where tribes have opportunities to simply harvest resources, they also want to tend those resources on public lands using traditional practices (Dobkins et al. 2016).

\section{Competition from non-Native Americans}

Impacts to tribal harvests by non-Native Americans is a longstanding issue, not only for salmon but also terrestrial resources including huckleberries, mushrooms, floral greens, and other forest products (Dobkins et al. 2016). One study found that some nontribal commercial harvesters, including immigrants from Southeast Asia and Latin America, had incentives to overharvest such resources because they were unlikely to recoup the benefit of leaving it, whereas tribal harvesters followed cultural practices that were more likely to favor sustainability (Richards and Creasy 1996).

\section{Strategies to foster sustainability}

Through our literature review, we identified several strategies that have been piloted and could address dimensions of socialecological traps (Table 1). For some of these strategies, public lands management agencies have a primary role in implementation; for others, their role may be more complementary. We focused heavily on managing the condition of forest resources and fire regimes because those activities are a core mission of federal land management agencies, unlike addressing problems that are more social and institutional in nature, such as poverty and land tenure. Those broader dimensions of the trap are important to consider and address. However, managing fire regimes and forests is a particularly important lever because tribes, scientists, and land management agencies increasingly share the belief that alteration of fire regimes has reduced the availability of desired conditions and increased vulnerability to more extreme and harmful wildfires. That shared understanding has included greater recognition of the interdependence of people and their forest environments and the need to withstand some short-term costs (such as having to conduct smaller burns more frequently) to achieve long-term benefits (Spies et al. 2014). Such changes in societal mindsets are important for escaping traps (Tidball 2016).

\section{Restoring fire regimes through adaptive management}

For several decades, researchers have recognized the loss of resilience in systems that historically experienced low intensity due to fire suppression. Carpenter and Brock (2008) and other researchers have highlighted "allowance for diverse fire regimes" as a general strategy for breaking out of a rigidity trap resulting from forest fire suppression. Similarly, Holling and Meffe (1996) called for an end to a fire suppression policy in such regions. However, simply ending fire suppression would create hazards and harms for both forest and human communities that have adapted to the lack of fire. For example, various species protected under federal law, including the northern spotted owl that was an impetus for the NWFP, are associated with thick forests. Both social and ecological factors make it difficult to break the cycle resulting from fire exclusion; consequently, the "paradox" of safely returning fire to social-ecological systems requires a whole range of social and land management strategies (Fernandes et al. 2011). In particular, escaping the trap will depend on shifting from command-and-control toward more novel and adaptive experimentation (especially in using fires), as well as engaging people in science and policy and monitoring and developing partnerships to accomplish restoration (Holling and Meffe 1996).

Exemplifying such an approach, the Western Klamath Restoration Partnership (WKRP) in northwestern California involves national forests, tribes, and a variety of community organizations in designing and implementing fire-centric strategies to reduce social and ecological vulnerability and support tribal ecocultural revitalization efforts (Harling 2015). It embodies an integrated approach to landscape restoration that seems consistent with broader strategies to escape socialecological traps, such as: (1) developing novel partnerships with both social and natural scientists and donors to build institutional capacity; (2) engaging in active adaptive management experiments to determine how to break detrimental feedbacks; and (3) focusing management actions at the broad scales relevant to key social and ecosystem processes and drivers (as opposed to small no-take reserves) (Cinner 2011). As examples of these strategies, the Karuk and Yurok Tribes have collaborated with scientists using grants to identify forest conditions that support traditional tribal foods and basketry materials. They have also partnered with various government agencies and nonprofit organizations such as The Nature Conservancy to build capacity for restoring landscape-scale fire across jurisdictional boundaries, through the TRaining EXchange (TREX) program, which shares cross-cultural fire knowledge while conducting strategic prescribed burns (Lake et al. 2017).

Active management, integrated with conservation of old forests, to promote a diverse and reliable supply of ecocultural resources Active management interventions, including understory and overstory thinning and judicious use of fire, are important for sustaining tribal ecocultural resources. These practices promote landscape biodiversity, productivity, and resilience to a warming climate and large or intense wildfires (Turner and Cocksedge 2001, Underwood et al. 2003, Turner et al. 2011). Such treatments appear particularly important to promote resilience in systems altered by historical timber harvest as well as more novel influences such as sudden oak death (Kuljian and Varner 2010). Conservation of old-growth forests is important to tribes for many reasons, including the use of large conifers such as redcedar as previously mentioned, and because large decadent or dead trees provide important habitat for culturally important species such marten and pileated woodpecker. Many hardwoods such as oaks, madrone (Arbutus menziesii), and bigleaf maple (Acer macrophyllum) also form valued large, old trees, although they depend upon fire to deter conifers from overtopping them. Research has demonstrated that burning, digging, thinning, trimming, weeding, and other interventions are important for sustaining the productivity and availability of many edible berries, 
roots, mushrooms, and seeds, along with other ecocultural resources that come from early successional forest openings or persistent nonforest communities (Turner and Cocksedge 2001, Wray and Anderson 2003, Peter and Shebitz 2006, Hamman et al. 2011, Turner et al. 2011, Anderson and Lake 2013). These communities support animals, including deer (Odocoileus spp.), elk, porcupine (Erethizon dorsatum), and many migratory birds, that are used for food and regalia (Wray and Anderson 2003, Lepofsky and Lertzman 2008). Promoting the variety of ecocultural resources desired by tribes depends upon maintaining a diversity of fire effects within large landscape areas that are suitable for harvesting over extended periods. As an example of this approach, the Skokomish Tribe and Quinault Indian Nation have worked with Olympic National Forest to restore beargrass and other native species using thinning and frequent burning (Shebitz et al. 2009).

\section{Addressing access}

Establishment of gathering areas on public lands that are reserved for tribal use appears to have been an effective solution to challenges afforded by competition with nontribal harvesters. In an important precedent, in 1932, the Gifford Pinchot National Forest agreed to reserve 1,130 ha of off-reservation huckleberry (Vaccinium spp.) patches for exclusive use by the Yakama Nation during huckleberry season under "the Handshake Agreement" (Fig. 4). The agreement was reached after the Yakama Chief Yallup asserted the tribe's treaty rights to harvest berries in the face of increasing impacts from non-Indians during the Great Depression (Fisher 1997), but it was not put into writing until 1990 (Richards and Alexander 2006). A similar approach was formalized more recently under a Memorandum of Understanding between the Mount Hood National Forest and the Confederated Tribes of the Warm Springs Reservation (Wang et al. 2002, Catton 2016).

Fig. 4. A sign marks the boundary of an exclusive gathering area set aside decades ago under the "Handshake Agreement" in a part of the Indian Heaven Wilderness, Gifford Pinchot National Forest, Washington, USA. Photo courtesy of Leslie Seaton.

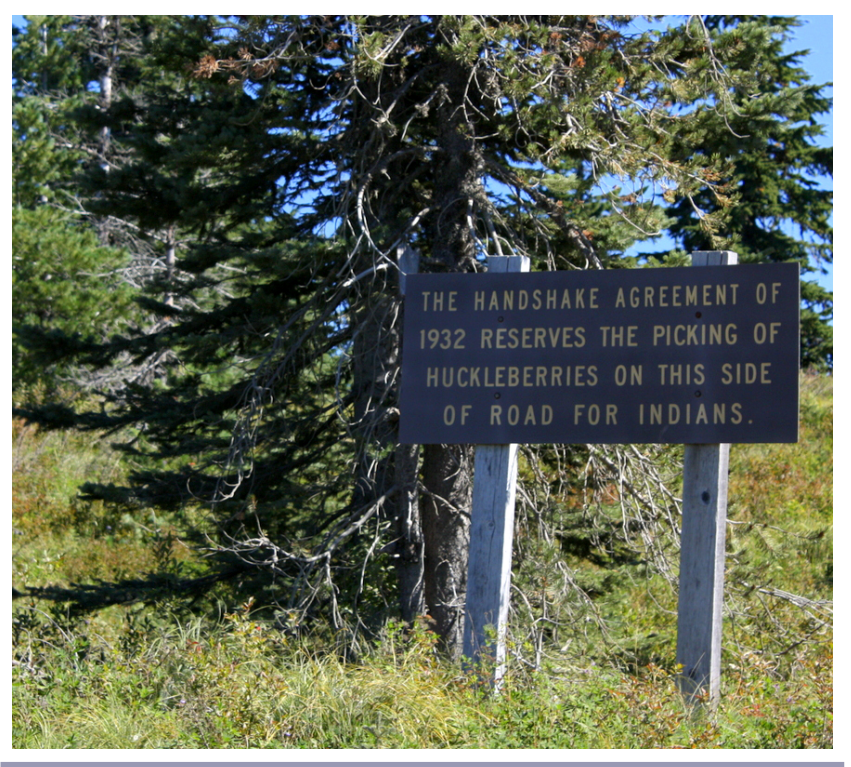

Managing roads is important because they provide access to both tribal practitioners and nontribal recreational users who could impact tribal resources. Because roads help tribal elders to access traditional harvesting areas, they are important for facilitating the sharing of traditional knowledge with younger generations (Dobkins et al. 2016). Establishment of some tribal stewardship areas has explicitly included reopening roads to key gathering sites (LeCompte-Mastenbrook 2016).

\section{Species reintroductions}

Reintroduction of ecological and cultural keystone species that have been extirpated, in conjunction with restoring their habitats, is an important strategy for sustaining tribal material uses, cultural values, biological diversity, and ecological processes. Reintroduction of gray wolves (Canis lupus) to parts of the Pacific Northwest, under leadership from the Nez Perce Tribe, has helped to restore biodiversity important to tribes and also enhanced tribal institutional interactions with federal agencies (Donoghue et al. 2010). The California condor (Gymnogyps californianus) is another tribally important species for which reintroduction within the Pacific Northwest has been considered (Walters et al. 2010).

\section{Dam removals}

Removing dams can restore hydrological disturbance processes and connectivity needed to enhance migratory fish populations (Pess et al. 2008), and thereby increase the availability of tribal aquatic ecocultural resources on public lands. In the last decade, several major dams have been intentionally removed within the NWFP area, notably the Elwha and Glines Canyon Dams in the ancestral lands of the Lower Elwha Klallam Tribe on the Olympic Peninsula (Pess et al. 2008), and the Condit Dam on the White Salmon River, a tributary of the Columbia River. More removals, including four dams on the Klamath River that impact several tribes, have been planned.

\section{Engaging tribes through cooperative management}

"Cooperative" or "collaborative" management has been applied to varying forms of tribal and federal influence on land management in an area, with the phrase "comanagement" often used when there is a legal mandate for shared management responsibilities (Nie 2008, Diver 2016). Collaborative partnerships with tribes, encompassing consideration of native knowledge, in planning, researching, implementing, and monitoring treatments within an adaptive ecosystem management framework fosters adaptive capacity of tribes and the partnering institutions. Such partnerships can build upon the foundations in the Tribal Forest Protection Act (U.S. Public Law 108-278) and many other laws and policies that provide for explicit tribal engagement and cooperative management, but they have to reckon with legacies of mistrust and inequity (Cronin and Ostergren 2007).

Tribes are concerned not only with ensuring that lands are actively tended, but also that they have opportunities to shape and conduct those efforts directly, rather than deferring management to nontribal employees or contractors. Partnerships that support traditional ecological knowledge, monitoring, and restoration of ecocultural resources, tribal institutional development, and intertribal resource management organizations, can foster tribal adaptive capacity (Whyte 2013). Goschke (2016) contended that successes in comanaging salmon provide an appropriate 
precedent for agencies to comanage terrestrial resources such as huckleberries with tribes and intertribal organizations. A number of stewardship agreements and/or designations of special tribal stewardship areas have supported tribes in applying traditional ecological knowledge and practices on national forest lands to achieve social and ecological objectives within the three states of the NWFP, including:

1. The Mt. Baker-Snoqualmie National Forest in Washington entered into a Memorandum of Agreement with the Tulalip Tribes in 2007 that supported cooperative efforts to sustain and enhance areas for treaty harvesting and other cultural practices, focusing on redcedar and huckleberries (LeCompte-Mastenbrook 2016). One particular outcome was establishment of a 518-ha "costewardship" area in the Skykomish watershed in 2011 to restore mountain meadows restoration and enhance huckleberry production by removing small conifers. The project has also included road maintenance to improve access and engagement of tribal youth to understand the benefits of treatments.

2. The Mount Baker-Snoqualmie National Forest settled a dispute with the Muckleshoot Tribe by designating special management areas for protection of cultural and historical features and for promotion of elk forage; portions of those areas were subsequently targeted for huckleberry enhancement (LeCompte-Mastenbrook 2016).

3. The Fremont-Winema National Forest in Oregon entered into a Master Stewardship Agreement and Supplemental Project Agreements with the Klamath Tribes that aim to restore forests, reduce risks of severe wildfires, train the tribal workforce, and enhance wood product processing capacity (Hatcher et al. 2017).

4. The Mount Hood National Forest in Oregon showcased the potential to set aside huckleberry tracts for exclusive tribal use and cooperatively manage the areas with Confederated Tribes of the Grande Ronde Community and Confederated Tribes of Warm Springs using prescribed fire and thinning on competing vegetation (Anzinger 2002, Wang et al. 2002).

5. The Willamette National Forest in Oregon has conducted restoration in collaboration with the Confederated Tribes of the Grande Ronde and the Confederated Tribes of the Siletz. Treatments within the Cougar Rock Special Interest Area included thinning and fuel reduction treatments to promote huckleberries and tribal access through road and campground development (Farque 2008), and treatments at the Camas Prairie project included prescribed burning and planting camas bulbs (Smith and Farque 2001).

6. Revisions to the land management plans for the Klamath and Six Rivers National Forests in California provided for the Karuk Tribe to apply cultural practices, including reintroduction of fire, within a specially designated Katimiin Cultural Management Area (Diver 2016).

7. The Forest Service Region 5 entered into a 10-year Master Stewardship Agreement with the Pit River Tribes and the Lomakatsi Restoration Project to conduct treatments on over 800,000 ha within the Lassen, Modoc, and ShastaTrinity National Forests in areas neighboring the NWFP area in northern California (USDA Forest Service 2015).
Synergies with broader sustainability strategies for public lands Strategies to promote tribal ecocultural resources appear congruent with emerging principles recommended by ecologists for restoring fire-prone inland Pacific forest landscapes, which focus on restoring disturbance regimes and associated ecological heterogeneity at multiple scales, while conserving old trees, biodiversity, and other important legacy resources (Hessburg et al. 2015, Hatcher et al. 2017). Managing both prescribed burns and wildfires is important for achieving resource objectives, including maintaining a diversity of open forests and woodlands with large hardwood trees, prairies, and wetlands. The NWFP paid insufficient attention to these ecological communities (Thomas et al. 2006). Although an emphasis on restoring fire is a greater need in drier ecosystem types that evolved with frequent fire from lightning ignitions, it is also important at fine scales within wetter ecosystem types. For example, active use of fire can help to sustain biodiversity in prairies, oak woodlands, and wetlands near the coast where lightning fires were less common but Native American influence was important (Engber et al. 2011, Schultz et al. 2011). Tribes have maintained that active tending practices can benefit human beings as well as a multitude of wildlife species by enhancing their foods and dwelling areas (Long et al. 2016). However, federal land management has generally followed a cautious a pproach of avoiding interventions in habitats of rare species that have declining populations (Anderson and Barbour 2003, Long et al. 2016). Tribal members have contended that management under the NWFP has allowed declines in important tribal ecocultural resources as a consequence of avoiding potential harm to late-successional forests, riparian areas, the northern spotted owl, and various "survey and manage species" (Harris 2011, Vinyeta and Lynn 2015, LeCompteMastenbrook 2016). Attention to tribal knowledge and values can help understand the effects and tradeoffs associated with management actions, and their absence, on broader ecological and sociocultural dimensions of sustainability. Such considerations have been overshadowed by the "jobs vs. owls" debates that have dogged the NWFP (Burnett and Davis 2002). Active restoration strategies can be integrated with efforts to conserve large, old trees and associated wildlife, cultural sites, and other ecocultural resources that are jeopardized by severe wildfires. In addition, such management can be counterbalanced with protective actions such as closure of roads or restrictions on recreational uses, when undertaken in a framework that considers a broad range of social and ecological values.

\section{Scaling up initiatives to overcome traps}

Although many strategies discussed above seek to improve both tribal well-being and ecological sustainability, transforming coupled social-ecological systems to achieve these goals may require a long and complicated process of adaptive experimentation to dismantle these long-standing traps. Progress is likely to depend on addressing the gamut of ecological and social factors that have strained the lasting relationships between tribes and the ecosystems of their ancestral lands. Although court decisions have addressed threats to species' persistence and tribal harvesting rights, broader restoration of public lands may ultimately yield more sustainable solutions. Reinstituting traditional practices and reestablishing relationships as part of a restoration strategy may need to overcome mental traps in which people fail to recognize interconnections between human actions 
and environmental processes or conditions (Tidball 2016). As one example, non-native managers, researchers, and members of the general public may mistakenly assume that an apparent absence of tribal harvest activity from public lands indicates a lack of interest by tribal members rather than a more complex degradation of the social-ecological system. When carried into decision making, such attitudes fulfill their own prophecy. Such notions may become increasingly difficult to counter as both human and ecological memories fade over time. However, surveys and interviews indicate that tribal members retain interest in harvesting traditional foods from public lands (Mucioki et al. 2018). By demonstrating the effects of reestablishing frequent fire and heterogeneous plant communities, implementation of tribal stewardship projects may catalyze broader social-ecological restoration by promoting groves of large, old conifer and hardwood trees, nonforest communities, and the benefits they provide to tribal communities. When developed in partnership with tribes and informed by tribal traditional knowledge, these efforts may counter tendencies to avoid active restoration by both demonstrating effectiveness of stewardship practices and encouraging shifts in mindsets. Evaluating and scaling up initiatives such as the WKRP and other examples that support tribal stewardship will be challenging because they are being implemented idiosyncratically across diverse social-ecological contexts, and they have to overcome the web of factors that reinforce the trap. However, a previous initiative designed to promote community well-being and ecological sustainability under the Northwest Forest Plan, the Jobs-in-the-Woods program, appeared comparatively successful where projects had strong support from tribal institutions (Middleton and Kusel 2007).

\section{CONCLUSION}

The theory of social-ecological traps helps to understand how interacting ecological and social factors, including colonization, diminished landscape diversity, productivity, and accessibility, have inhibited tribal well-being and stewardship within their ancestral territories. Greater understanding of such traps can help to shift mindsets of decision makers and members of the public. In particular, it can help to replace overly simplistic ideologies of protecting "naturalness" and "wilderness" or producing more ecosystem services to benefit humans, with more complex notions of sustaining coevolved, reciprocal relationships between people and their environment (Winthrop 2014, Pascua et al. 2017). Scientific publications increasingly recognize the historical influence of Native Americans on ecosystems in the Pacific Northwest, and how beneficial disturbances, such as wildland fires and tribal tending practices, can sustain the productivity, diversity, and resilience of social and ecological systems. Recent partnerships involving government agencies, nonprofit organizations, and tribes illustrate compelling opportunities for reinvigorating those ancient connections to both benefit tribal communities and foster broader sustainability of national forests in the region. These approaches can help break social-ecological traps by reestablishing tribal ecocultural stewardship across public lands in the Pacific Northwest region.

Responses to this article can be read online at: http://www.ecologyandsociety.org/issues/responses. php/10041

\section{Acknowledgments:}

We thank Kathy Lynn and Carson Viles for contributing valuable content to the larger synthesis report upon which this article was based, peer reviewers and members of the public who provided feedback on that report, and numerous individuals who have contributed to collaborative and integrative research efforts regarding tribal ecocultural resources.

\section{LITERATURE CITED}

Agrawal, A. 2002. Indigenous knowledge and the politics of classification. International Social Science Journal 54(173):287297. http://dx.doi.org/10.1111/1468-2451.00382

Anderson, M. K. 2005. Tending the wild: Native American knowledge and the management of California's natural resources. University of California Press, Berkeley, California, USA.

Anderson, M. K., and M. G. Barbour. 2003. Simulated indigenous management: a new model for ecological restoration in national parks. Ecological Restoration 21(4):269-277. http:// dx.doi.org/10.3368/er.21.4.269

Anderson, M. K., and F. K. Lake. 2013. California Indian ethnomycology and associated forest management. Journal of Ethnobiology 33(1):33-85. http://dx.doi.org/10.2993/0278-0771-33.1.33

Anzinger, D. 2002. Big huckleberry (Vaccinium membranaceum Dougl.) ecology and forest succession, Mt. Hood National Forest and Warm Springs Indian Reservation, Oregon. Thesis, University of Oregon, Corvallis, Oregon, USA.

Bowcutt, F. 2013. Tanoak landscapes: tending a Native American nut tree. Madroño 60(2):64-86. http://dx.doi.org/10.3120/0024-9637-60.2.64

Boyd, R. 1999. The coming of the spirit of pestilence: introduced infectious diseases and population decline among Northwest Coast Indians, 1774-1874. University of Washington, Seattle, Washington, USA.

Breslow, S. J. 2014. Tribal science and farmers' resistance: a political ecology of salmon habitat restoration in the American Northwest. Anthropological Quarterly 87(3):727-758. http://dx. doi.org/10.1353/anq.2014.0045

Burnett, M., and C. Davis. 2002. Getting out the cut. Administration and Society 34(2):202-228. http://dx.doi. org/10.1177/0095399702034002004

Bussey, J., M. A. Davenport, M. R. Emery, and C. Carroll. 2016. "A lot of it comes from the heart": the nature and integration of ecological knowledge in tribal and nontribal forest management. Journal of Forestry 114(2):97-107. http://dx.doi.org/10.5849/ jof.14-130

Campbell, S., and V. Butler. 2010. Archaeological evidence for resilience of Pacific Northwest salmon populations and the socioecological system over the last $\sim 7,500$ years. Ecology and Society 15(1): 17. http://dx.doi.org/https://doi.org/10.5751/ ES-03151-150117

Carpenter, S., and W. Brock. 2008. Adaptive capacity and traps. Ecology and Society 13(2): 40. http://dx.doi.org/10.5751/ ES-02716-130240 
Catton, T. 2016. American Indians and national forests. University of Arizona Press, Tucson, Arizona, USA.

Charnley, S., C. Dillingham, C. Stuart, C. Moseley, and E. M. Donoghue. 2008. Northwest forest plan - the first 10 years (19942003 ): socioeconomic monitoring of the Klamath National Forest and three local communities. General Technical Report PNWGTR-764, U.S. Department of Agriculture, Forest Service, Pacific Northwest Research Station, Portland, Oregon, USA.

Cinner, J. E. 2011. Social-ecological traps in reef fisheries. Global Environmental Change-Human and Policy Dimensions 21(3):835839. http://dx.doi.org/10.1016/j.gloenvcha.2011.04.012

Cocking, M. I., J. M. Varner, and E. E. Knapp. 2014. Long-term effects of fire severity on oak-conifer dynamics in the southern Cascades. Ecological Applications 24(1):94-107. http://dx.doi. org/10.1890/13-0473.1

Coder, C., V. Randall, E. Smith-Rocha, and R. Hines. 2005. Chi ch'il (acorns): dissolution of traditional Dilzhe'e gathering practice(s) due to federal control of the landscape. Pages 277-281 in G. J. Gottfried, B. S. Gebow, L. G. Eskew, C. B. Edminster, editors. Connecting mountain islands and desert seas: biodiversity and management of the Madrean Archipelago II. Proceedings RMRS-P-36, USDA Forest Service, Rocky Mountain Research Station, Fort Collins, Colorado, USA.

Colombi, B. J. 2012. Salmon and the adaptive capacity of Nimiipuu (Nez Perce) culture to cope with change. The American Indian Quarterly 36(1):75-97. http://dx.doi.org/https://doi. org/10.5250/amerindiquar.36.1.0075

Coops, N. C., and R. H. Waring. 2011. Estimating the vulnerability of fifteen tree species under changing climate in northwest North America. Ecological Modelling 222(13):21192129. http://dx.doi.org/10.1016/j.ecolmodel.2011.03.033

Cornell, S., and J. P. Kalt. 1998. Sovereignty and nation-building: the development challenge in Indian country today. American Indian Culture and Research Journal 22(3):187-214. http://dx.doi. org/10.17953/aicr.22.3.1v45536553vn7j78

Cronin, A., and D. Ostergren. 2007. Tribal watershed management: culture, science, capacity and collaboration. The American Indian Quarterly 31(1):87-109. http://dx.doi.org/10.1353/ aiq.2007.0004

Cuerrier, A., N. J. Turner, T. C. Gomes, A. Garibaldi, and A. Downing. 2015. Cultural keystone places: conservation and restoration in cultural landscapes. Journal of Ethnobiology 35 (3):427-448. http://dx.doi.org/10.2993/0278-0771-35.3.427

Delano, C. 1872. Annual report of the Secretary of the Interior on the operations of the Department for 1872. U.S. Government Printing Office, Washington, D.C., USA. [online] URL: https:// en.wikisource.org/wiki/Report of the Secretary_of the Interior/1872

Diver, S. 2016. Co-management as a catalyst: pathways to postcolonial forestry in the Klamath Basin, California. Human Ecology 44(5):533-546. http://dx.doi.org/10.1007/s10745-016-9851-8

Dobkins, R., C. Lewis, S. Hummel, and E. Dickey. 2016. Cultural plant harvest on federal lands: perspectives from members of the Northwest Native American Basketweavers Association. Research paper PNW-RP-608, USDA Forest Service, Pacific Northwest Research Station, Portland, Oregon, USA.

Donoghue, E., S. Thompson, and J. C. Bliss. 2010. Tribal-federal collaboration in resource management. Journal of Ecological Anthropology 14(1):22-38. http://dx.doi.org/10.5038/2162-4593.14.1.2

Ellis, S. C. 2005. Meaningful consideration? A review of traditional knowledge in environmental decision making. Arctic 58(1):66-77. http://dx.doi.org/10.14430/arctic390

Enfors, E. 2013. Social-ecological traps and transformations in dryland agro-ecosystems: using water system innovations to change the trajectory of development. Global Environmental Change 23(1):51-60. http://dx.doi.org/10.1016/j.gloenvcha.2012.10.007

Engber, E. A., J. M. Varner, L. A. Arguello, and N. G. Sugihara. 2011. The effects of conifer encroachment and overstory structure on fuels and fire in an oak woodland landscape. Fire Ecology 7 (2):32-50. http://dx.doi.org/10.4996/fireecology.0702032

Espy, M., and B. Babbit. 1994. Record of decision: amendments to Forest Service and Bureau of Land Management planning documents within the range of the Northern Spotted Owl. U.S. Government Printing Office, Washington, D.C., USA.

Farque, T. 2008. Cougar Rock huckleberry enhancement project. Willamette National Forest, Sweethome Ranger District, USDA Forest Service. Powerpoint presentation. [online] URL: https:// ecoshare.info/wp-content/uploads/2012/03/Farque.pdf

Fernandes, P. M., F. C. Rego, and E. Rigolot. 2011. The FIRE PARADOX project: towards science-based fire management in Europe. Forest Ecology and Management 261(12):2177-2178. http://dx.doi.org/10.1016/j.foreco.2010.12.024

Fisher, A. H. 1997. The 1932 handshake agreement: Yakama Indian treaty rights and Forest Service policy in the Pacific Northwest. Western Historical Quarterly 28(2):186-217. http:// dx.doi.org/https://doi.org/10.2307/970893

Gabriel, M. W., G. M. Wengert, J. M. Higley, S. Krogan, W. Sargent, and D. L. Clifford. 2013. Silent forests: rodenticides on illegal marijuana crops harm wildlife. The Wildlife Professional 7 (1):46-50.

Garibaldi, A., and N. Turner. 2004. Cultural keystone species: implications for ecological conservation and restoration. Ecology and Society 9(3): 1. http://dx.doi.org/10.5751/ES-00669-090301

Gavin, M. C., J. McCarter, A. Mead, F. Berkes, J. R. Stepp, D. Peterson, and R. Tang. 2015. Defining biocultural approaches to conservation. Trends in Ecology and Evolution 30(3):140-145. http://dx.doi.org/10.1016/j.tree.2014.12.005

Goschke, L. 2016. Tribes, treaties, and the trust responsibility: a call for co-management of huckleberries in the Northwest. Colorado Natural Resources Energy and Environmental Law Review 27:316-360.

Gosnell, H., and E. C. Kelly. 2010. Peace on the river? Socialecological restoration and large dam removal in the Klamath basin, USA. Water Alternatives 3(2):362-383.

Greeley, W. B. 2000. "Piute forestry" or the fallacy of light burning. Fire Management Today 60(4):21-26. 
Halofsky, J. E., D. L. Peterson, K. L. Metlen, M. G. Myer, and V. A. Sample. 2016. Developing and implementing climate change adaptation options in forest ecosystems: a case study in southwestern Oregon, USA. Forests 7(11): 268. http://dx.doi. org/10.3390/f7110268

Halpern, A. A. 2016. Prescribed fire and tanoak (Notholithocarpus densifolius) associated cultural plant resources of the Karuk and Yurok people of California. Dissertation, University of California at Berkeley, Berkeley, California, USA.

Hamman, S. T., P. W. Dunwiddie, J. L. Nuckols, and M. McKinley. 2011. Fire as a restoration tool in Pacific Northwest prairies and oak woodlands: challenges, successes, and future directions. Northwest Science 85(2):317-328. http://dx.doi.org/10.3955/046.085.0218

Harling, W. 2015. Learning together, burning together. Wildfire Magazine 24(1):26-30.

Harris, G. 2011. Northwest forest plan-the first 15 years [19942008]: Effectiveness of the federal-tribal relationship. Technical Paper R6-RPM-TP-01-2011, U.S. Department of Agriculture, Forest Service, Pacific Northwest Region, Portland, Oregon, USA.

Hatcher, W., S. Rondeau, D. L. Johnson, K. N. Johnson, and J. F. Franklin. 2017. Klamath Tribes-managing their homeland forests in partnership with the USDA Forest Service. Journal of Forestry 115(5):447-455. http://dx.doi.org/10.5849/jof.16-027

Hessburg, P. F., D. J. Churchill, A. J. Larson, R. D. Haugo, C. Miller, T. A. Spies, M. P. North, N. A. Povak, R. T. Belote, P. H. Singleton, W. L. Gaines, R. E. Keane, G. H. Aplet, S. L. Stephens, P. Morgan, P. A. Bisson, B. E. Rieman, R. B. Salter, and G. H. Reeves. 2015. Restoring fire-prone inland Pacific landscapes: seven core principles. Landscape Ecology 30(10):1805-1835. http://dx.doi.org/10.1007/s10980-015-0218-0

Holling, C. S., and G. K. Meffe. 1996. Command and control and the pathology of natural resource management. Conservation Biology 10(2):328-337. http://dx.doi.org/10.1046/

j.1523-1739.1996.10020328.x

Huntsinger, L., and S. McCaffrey. 1995. A forest for the trees: forest management and the Yurok environment, 1850 to 1994. American Indian Culture and Research Journal 19(4):155-192. http://dx.doi.org/https://doi.org/10.17953/aicr.19.4.cv0758kh373323h1

Jack, K. R. 1916. An Indian's view of burning, and a reply. California Fish and Game Journal 2(4):194-196.

Karuk Tribe and Cultural Solutions. 1999. Karuk forest management perspectives: interviews with tribal members, Vol. 2: Appendices. Report prepared for USDA Forest Service, Klamath National Forest, Yreka, California, USA.

Keller, R. H., and M. F. Turek. 1999. American Indians and national parks. University of Arizona Press, Tucson, Arizona, USA.

Koricheva, J., and J. Gurevitch. 2013. Place of meta-analysis among other methods of research synthesis. Pages 3-13 in J. Koricheva, J.Gurevitch, and K. Mengersen,editors. Handbook of meta-analysis in Ecology and Evolution. Princeton University
Press, Princeton, New Jersey, USA. http://dx.doi.org/https://doi. org/10.1515/9781400846184-003

Kuljian, H., and J. M. Varner. 2010. The effects of sudden oak death on foliar moisture content and crown fire potential in tanoak. Forest Ecology and Management 259(10):2103-2110. http://dx.doi.org/10.1016/j.foreco.2010.02.022

Lake, F. K., V. Wright, P. Morgan, M. McFadzen, D. McWethy, and C. Stevens-Rumann. 2017. Returning fire to the land: celebrating traditional knowledge and fire. Journal of Forestry 115 (5):343-353. http://dx.doi.org/10.5849/jof.2016-043R2

LeCompte-Mastenbrook, J. K. 2016. Restoring Coast Salish foods and landscapes: a more-than-human politics of place, history and becoming. University of Washington, Seattle, Washington, USA.

Leopold, A. 1920. "Piute forestry" vs. forest fire prevention. Southwestern Magazine 2:12-13.

Lepofsky, D., and K. Lertzman. 2008. Documenting ancient plant management in the northwest of North America. Botany 86 (2):129-145. http://dx.doi.org/https://doi.org/10.1139/B07-094

Long, J. W., M. K. Anderson, L. N. Quinn-Davidson, R. W. Goode, F. K. Lake, and C. N. Skinner. 2016. Restoring California black oak ecosystems to promote tribal values and wildlife. General Technical Report PSW-GTR-252, U.S. Department of Agriculture, Forest Service, Pacific Southwest Research Station, Albany, California, USA.

Long, J. W., L. Quinn-Davidson, and C. N. Skinner. 2014. Science synthesis to support socioecological resilience in the Sierra Nevada and southern Cascade Range. General Technical Report PSWGTR-247 U.S. Department of Agriculture, Forest Service, Pacific Southwest Research Station, Albany, California, USA. http://dx. doi.org/10.2737/PSW-GTR-247

Lynn, K., J. Daigle, J. Hoffman, F. Lake, N. Michelle, D. Ranco, C. Viles, G. Voggesser, and P. Williams. 2013. The impacts of climate change on tribal traditional foods. Climatic Change 120 (3):545-556. http://dx.doi.org/https://doi.org/10.1007/s10584-013-0736-1

Lynn, K., K. MacKendrick, and E. M. Donoghue. 2011. Social vulnerability and climate change: synthesis of literature. General Technical Report PNW-GTR-838, U.S. Department of Agriculture, Forest Service, Pacific Northwest Research Station, Portland, Oregon, USA. http://dx.doi.org/10.2737/PNWGTR-838

MacDougall, A. S. 2008. Herbivory, hunting, and long-term vegetation change in degraded savanna. Biological Conservation 141(9):2174-2183. http://dx.doi.org/10.1016/j.biocon.2008.07.003

Mack, C. A., and R. H. McClure. 2002. Vaccinium processing in the Washington Cascades. Journal of Ethnobiology 22(1):35-60.

MacKendrick, K. 2009. Climate change adaptation planning for cultural and natural resource resilience: a look at planning for climate change in two native nations in the Pacific Northwest U.S. Thesis, University of Oregon, Eugene, Oregon, USA.

Middleton, B. R., and J. Kusel. 2007. Northwest economic adjustment initiative assessment: lessons learned for American Indian community and economic development. Economic Development Quarterly 21(2):165-178. http://dx.doi. org/10.1177/0891242406298136 
Miller, J. D., C. N. Skinner, H. D. Safford, E. E. Knapp, and C. M. Ramirez. 2012. Trends and causes of severity, size, and number of fires in northwestern California, USA. Ecological Applications 22(1):184-203. http://dx.doi.org/10.1890/10-2108.1

Mucioki, M., J. Sowerwine, and D. Sarna-Wojcicki. 2018. Thinking inside and outside the box: local and national considerations of the Food Distribution Program on Indian Reservations (FDPIR). Journal of Rural Studies 57:88-98. http:// dx.doi.org/10.1016/i.jrurstud.2017.11.002

Nie, M. 2008. The use of co-management and protected land-use designations to protect tribal cultural resources and reserved treaty rights on federal lands. Natural Resources Journal 48:585647.

Norgaard, K. M. 2014a. Karuk traditional ecological knowledge and the need for knowledge sovereignty: Social, cultural and economic impacts of denied access to traditional management. Karuk Tribe Department of Natural Resources, Orleans, California, USA.

Norgaard, K. M. 2014b. The politics of fire and the social impacts of fire exclusion on the Klamath. Humboldt Journal of Social Relations 36:77-101.

Norgaard, K. M., R. Reed, and J. Bacon. 2017. How environmental decline restructures indigenous gender practices: what happens to Karuk masculinity when there are no fish? Sociology of Race and Ethnicity (2332649217706518):1-16.

Norgaard, K. M., R. Reed, and C. van Horn. 2011. A continuing legacy: institutional racism, hunger, and nutritional justice on the Klamath. Pages 23-46 in A. H. Alkon and J. Agyeman, editors. Cultivating food justice: race, class, and sustainability. MIT Press, Cambridge, Massachusetts, USA.

Norton-Smith, K., K. Lynn, K. Chief, K. Cozzetto, J. Donatuto, M. H. Redsteer, L. E. Kruger, J. Maldonado, C. Viles, and K. P. Whyte. 2016. Climate change and indigenous peoples: a synthesis of current impacts and experiences. General Technical Report PNW-GTR-944, U.S. Department of Agriculture, Forest Service, Pacific Northwest Research Station, Portland, Oregon, USA.

Office of the Federal Register. 2012. Subpart A: national forest system land management planning. Pages 21260-21276. 36 CFR Part 219. U.S. Government Printing Office, Washington, D.C., USA.

Papiez, C. 2009. Climate change implications for the Quileute and Hoh tribes of coastal Washington: a multidisciplinary approach to assessing climatic disruptions to coastal indigenous communities. Thesis, Evergreen State College, Olympia, Washington, USA.

Papworth, S. K., J. Rist, L. Coad, and E. J. Milner-Gulland. 2009. Evidence for shifting baseline syndrome in conservation. Conservation Letters 2(2):93-100. http://dx.doi.org/10.1111/ j.1755-263X.2009.00049.X

Pascua, P. A., H. McMillen, T. Ticktin, M. Vaughan, and K. B. Winter. 2017. Beyond services: a process and framework to incorporate cultural, genealogical, place-based, and indigenous relationships in ecosystem service assessments. Ecosystem Services 26(Part B):465-475. http://dx.doi.org/10.1016/j. ecoser.2017.03.012
Peek, J. M., B. Dennis, and T. Hershey. 2002. Predicting population trends of mule deer. The Journal of Wildlife Management 66(3):729-736. http://dx.doi.org/10.2307/3803138

Pess, G. R., M. L. McHenry, T. J. Beechie, and J. Davies. 2008. Biological impacts of the Elwha River dams and potential salmonid responses to dam removal. Northwest Science 82(sp1): 72-90. http://dx.doi.org/10.3955/0029-344X-82.S.I.72

Peter, D., and D. Shebitz. 2006. Historic anthropogenically maintained bear grass savannas of the southeastern Olympic Peninsula. Restoration Ecology 14(4):605-615. http://dx.doi. org/10.1111/j.1526-100X.2006.00172.X

Pfeiffer, J. M., and E. H. Ortiz. 2007. Invasive plants impact California native plants used in traditional basketry. Fremontia 35(1):7-13.

Record, I. W. 2008. We are the stewards: indigenous-led fisheries innovation in North America. Joint Occasional Papers on Native Affairs 1931143390, Native Nations Institute for Leadership, Management, and Policy, University of Arizona, and the Harvard Project on American Indian Economic Development, Harvard University, Tucson, Arizona, USA.

Reilly, M. J., C. J. Dunn, G. W. Meigs, T. A. Spies, R. E. Kennedy, J. D. Bailey, and K. Briggs. 2017. Contemporary patterns of fire extent and severity in forests of the Pacific Northwest, USA (1985-2010). Ecosphere 8(3): e01695. http://dx.doi.org/https:// doi.org/10.1002/ecs2.1695

Richards, R. T., and S. J. Alexander. 2006. A social history of wild huckleberry harvesting in the Pacific Northwest. General Technical Report PNW-GTR-657, U.S. Department of Agriculture, Forest Service, Pacific Northwest Research Station, Portland, Oregon, USA. http://dx.doi.org/10.2737/PNW-GTR-657

Richards, R. T., and M. Creasy. 1996. Ethnic diversity, resource values, and ecosystem management: matsutake mushroom harvesting in the Klamath bioregion. Society and Natural Resources 9(4):359-374. http://dx.doi.org/10.1080/08941929609380980

Schultz, C. B., E. Henry, A. Carleton, T. Hicks, R. Thomas, A. Potter, M. Collins, M. Linders, C. Fimbel, and S. Black. 2011. Conservation of prairie-oak butterflies in Oregon, Washington, and British Columbia. Northwest Science 85(2):361-388. http:// dx.doi.org/10.3955/046.085.0221

Shebitz, D. J., S. H. Reichard, and P. W. Dunwiddie. 2009. Ecological and cultural significance of burning beargrass habitat on the Olympic Peninsula. Ecological Restoration 27(3):306-319. http://dx.doi.org/10.3368/er.27.3.306

Smith, A., and T. Farque. 2001. The Camas Prairie restoration project re-establishes an indigenous cultural landscape (Oregon). Ecological Restoration 19:107-108.

Spies, T. A., E. M. White, J. D. Kline, A. P. Fischer, A. Ager, J. Bailey, J. Bolte, J. Koch, E. Platt, C. S. Olsen, D. Jacobs, B. Shindler, M. M. Steen-Adams, and R. Hammer. 2014. Examining fire-prone forest landscapes as coupled human and natural systems. Ecology and Society 19(3): 9. http://dx.doi.org/10.5751/ ES-06584-190309

Strickland, C. J., E. Walsh, and M. Cooper. 2006. Healing fractured families: parents' and elders' perspectives on the impact 
of colonization and youth suicide prevention in a Pacific Northwest American Indian Tribe. Journal of Transcultural Nursing 17(1):5-12. http://dx.doi.org/10.1177/1043659605281982

Stuart, C., and K. Martine. 2005. Northwest Forest Plan, the first 10 years (1994-2003): effectiveness of the federal-tribal relationship. Technical Publication R6-RPM-TP-01-2011, U.S. Department of Agriculture, Forest Service, Pacific Northwest Region, Portland, Oregon, USA.

Thomas, J. W., J. F. Franklin, J. Gordon, and K. N. Johnson. 2006. The Northwest Forest Plan: origins, components, implementation experience, and suggestions for change. Conservation Biology 20 (2):277-287. http://dx.doi.org/10.1111/j.1523-1739.2006.00385. $\underline{\mathrm{X}}$

Tidball, K., N. Frantzeskaki, and T. Elmqvist. 2016. Traps! An introduction to expanding thinking on persistent maladaptive states in pursuit of resilience. Sustainability Science 11(6):861866. http://dx.doi.org/10.1007/s11625-016-0398-9

Tidball, K. G. 2016. Traps in and of our minds: relationships between human logic, dialectical traps and social-ecological traps. Sustainability Science 11(6):867-876. http://dx.doi.org/10.1007/ s11625-016-0396-y

Trosper, R. L. 2002. Northwest coast indigenous institutions that supported resilience and sustainability. Ecological Economics 41 (2):329-344. http://dx.doi.org/10.1016/S0921-8009(02)00041-1

Trosper, R. L. 2003. Resilience in pre-contact Pacific Northwest social ecological systems. Conservation Ecology 7(3): 6. http://dx. doi.org/10.5751/ES-00551-070306

Turner, N. J., and W. Cocksedge. 2001. Aboriginal use of nontimber forest products in northwestern North America. Journal of Sustainable Forestry 13(3-4):31-58. http://dx.doi.org/https:// doi.org/10.1300/J091v13n03 04

Turner, N. J., I. J. Davidson-Hunt, and M. O'Flaherty. 2003. Living on the edge: ecological and cultural edges as sources of diversity for social-ecological resilience. Human Ecology 31 (3):439-461. http://dx.doi.org/https://doi.org/10.1023/A:1025023906459

Turner, N. J., D. Deur, and D. Lepofsky. 2013. Plant management systems of British Columbia's first peoples. B.C. Studies (179):107-133.

Turner, N. J., D. Deur, and C. R. Mellot. 2011. "Up on the mountain": ethnobotanical importance of montane sites in Pacific coastal North America. Journal of Ethnobiology 31(1):4 43. http://dx.doi.org/10.2993/0278-0771-31.1.4

Underwood, S., L. Arguello, and N. Siefkin. 2003. Restoring ethnographic landscapes and natural elements in Redwood National Park. Ecological Restoration 21(4):278-83. http://dx. doi.org/10.3368/er.21.4.278

USDA Forest Service. 2015. Master stewardship agreement between the Pit River Tribe and the Lomakatski Restoration Project and the USDA Forest Service, Lassen, Modoc, and Shasta-Trinity National Forests. U.S. Department of Agriculture, Tribal Relations Program, Washington, D.C., USA. [online] URL: https://www.fs.fed.us/spf/tribalrelations/documents/agreements/15SA-11052000-056.pdf
Vinyeta, K., and K. Lynn. 2015. Strengthening the federal-tribal relationship: a report on monitoring consultation under the Northwest Forest Plan. Report FS/R6/PNW/2015/005, USDA Forest Service Pacific Northwest Region, Portland, Oregon, USA.

Voggesser, G., K. Lynn, J. Daigle, F. Lake, and D. Ranco. 2013. Cultural impacts to tribes from climate change influences on forests. Climatic Change 120(3):615-626. http://dx.doi.org/ https://doi.org/10.1007/s10584-013-0733-4

Walters, J. R., S. R. Derrickson, D. Michael Fry, S. M. Haig, J. M. Marzluff, and J. M. Wunderle. 2010. Status of the California condor (Gymnogyps californianus) and efforts to achieve its recovery. The Auk 127(4):969-1001. http://dx.doi.org/10.1525/ auk.2010.127.4.969

Wang, G. A., D. H. Anderson, and P. J. Jakes. 2002. Heritage management in the U.S. Forest Service: a Mount Hood National Forest case study. Society and Natural Resources 15(4):359-369. http://dx.doi.org/https://doi.org/10.1080/089419202753570837

White, S. E. 1920. Getting at the truth: is the Forest Service really trying to lay bare the facts of the light-burning theory. Sunset, the Pacific Monthly 5(62):80-82.

Whyte, K. P. 2013. Justice forward: tribes, climate adaptation and responsibility. Climatic Change 120(3):517-530. http://dx.doi. org/https://doi.org/10.1007/s10584-013-0743-2

Willette, M., K. Norgaard, R. Reed, and K. Tribe. 2016. You got to have fish: families, environmental decline and cultural reproduction. Families, Relationships and Societies 5:375-392. http://dx.doi.org/10.1332/204674316X14758424912055

Winthrop, R. H. 2014. The strange case of cultural services: limits of the ecosystem services paradigm. Ecological Economics 108 (Supplement C):208-214. http://dx.doi.org/10.1016/j. ecolecon.2014.10.005

Wood, M. C. 1995. Fulfilling the executive's trust responsibility toward the native nations on environmental issues: a partial critique of the Clinton administration's promises and performance. Environmental Law 25(3):733-800.

Wood, W. 2008. The trajectory of Indian Country in California: rancherías, villages, pueblos, missions, ranchos, reservations, colonies, and rancherias. Tulsa Law Review 44(2):17-364.

Woods, F. 2005. Who's in charge of fishing? Oregon Historical Quarterly 106(3):412-441.

Wray, J., and M. K. Anderson. 2003. Restoring Indian-set fires to prairie ecosystems on the Olympic Peninsula. Ecological Restoration 21(4):296-301. http://dx.doi.org/10.3368/er.21.4.296

Zald, H. S. 2009. Extent and spatial patterns of grass bald land cover change (1948-2000), Oregon Coast Range, USA. Plant Ecology 201(2):517-529. http://dx.doi.org/https://doi.org/10.1007/ s11258-008-9511-1 